\title{
Does Blood Oxygen Level Influence on Tomato Likeliness?
}

\author{
Muhammad Imran Qadir and Ayesha Munir* \\ Institute of Molecular Biology and Biotechnology, Pakistan \\ *Corresponding author: Ayesha Munir, Institute of Molecular Biology and Biotechnology, Pakistan
}

$\overline{\text { ARTICLE INFO }} \quad$ ABSTRACT

Received: 蔧 January 31, 2019

Published: March 05, 2019

Citation: Muhammad Imran Qadir, Ayesha Munir. Does Blood Oxygen Level Influence on Tomato Likeliness?. Biomed J Sci \& Tech Res 15(3)-2019. BJSTR. MS.ID.002706.
Blood oxygen level is used to calculate how much oxygen and carbon dioxide red blood cells are transferring. A blood oxygen level analysis also examines the stability of acids and bases, recognised as pH balance, in the blood. The main topic of this research is the tomato likeliness. As some people likes more tomatoes than others and they use tomato in different ways. The main topic of this research is the tomato likeliness. As some people likes more tomatoes than others and they use tomato in different ways.

Keywords: Oxygen level; Tomato likeliness; Pulse Oximeter; Significant

\section{Introduction}

\section{Blood Oxygen Level}

Blood oxygen level is used to calculate how much oxygen and carbon dioxide red blood cells are transferring. Our body controls our blood oxygen level. Sustaining the specific balance of oxygensaturated blood is essential to our health [1,2]. Maximum kids and grownups don't require to observe their blood oxygen level. Though, people with enduring or chronic healthiness situations may need to check their blood oxygen level. In these cases, observing blood oxygen level can benefit to control if cure is working, or if they should be modified [3,4]. A blood oxygen level analysis also examines the stability of acids and bases, recognised as $\mathrm{pH}$ balance, in the blood. Too abundant or too minute acid in the blood can denote there is a complication with your lungs or with your kidneys. Most blood examinations catch a taster or sample from a vein. For this analysis, a health maintenance provider will take a taster or sample of blood from an artery.

That's for the reason that blood from an artery has high oxygen levels than the blood coming from a vein. The sample is generally taken from an artery in the interior of wrist. This is termed as the radial artery.

The main topic of this research is the tomato likeliness. As some people likes more tomatoes than others and they use tomato in different ways [4-7]. Some people like tomatoes in salads and some people likes in different forms. Actually, blood group has an influence on tomato likeliness. As people with blood group 0 positive likes more tomatoes than others. And B negative are very little attracted to tomatoes $[8,9]$. The main topic of this research is the tomato likeliness. As some people likes more tomatoes than others and they use tomato in different ways.

\section{Materials and Methods}

\section{Calculation of Blood Oxygen Level}

Blood Oxygen level or Peripheral oxygen saturation is an estimation of oxygen saturation level frequently calculated with a device called as pulse oximeter [10]. It can be measured with pulse oximetry as in consonance with the given formula:s

$$
\mathrm{S}_{P} \mathrm{O}_{2}=\frac{\mathrm{HbO}_{2}}{\mathrm{HbO}_{2}+\mathrm{Hb}}
$$

Here $\mathrm{HbO}_{2}$ is oxygenated hemoglobin and $\mathrm{Hb}$ is the deoxygenated hemoglobin.

\section{Statistical Analysis}

Statistical analysis was achieved by applying the M state software. t-Test was used to evaluate the end result. $\mathrm{P}<0.05$ was regarded as a most significant value.

\section{Results}

Association of normal blood oxygen level ( Mean \pm SD ) with Tomato likeliness (Table 1). $\mathrm{P}<0.05$ mean the value is significant. 
Table 1: Association of normal blood oxygen level ( Mean \pm SD ) with Tomato likeliness.

\begin{tabular}{|c|c|c|c|}
\hline Gender & $\begin{array}{c}\text { Tomato } \\
\text { Likeliness }\end{array}$ & $\begin{array}{c}\text { Tomato } \\
\text { Dislikeliness }\end{array}$ & P Value \\
\hline Male & $94.74 \pm 4.47$ & $92.28 \pm 6.08$ & $0.03^{*}$ \\
\hline Female & $92.44 \pm 6.05$ & $93.21 \pm 6.85$ & 0.52 \\
\hline Combined & $93.16 \pm 5.69$ & $92.75 \pm 6.46$ & 0.63 \\
\hline
\end{tabular}

\section{Conclusion}

From this questionnaire it is concluded that normal blood oxygen level has influence on tomato likeliness. Because the $\mathrm{P}$ value is less than 0.05 and is significant.

\section{References}

1. Eenglish MP (1976) Nails and fungi. British Journal of Dermatology 94(6): 697-701.

2. Gentles JC, Evans EG (1970) Infection of the feet and nails with Hendersonula toruloidea. Sabouraudia: Journal of Medical and Veterinary Mycology 8(1): 72-75.

\section{ISSN: 2574-1241}

DOI: 10.26717/BJSTR.2019.15.002706

Ayesha Munir. Biomed J Sci \& Tech Res

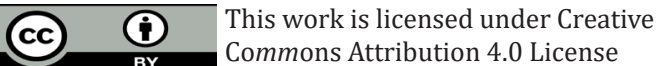

Submission Link: https://biomedres.us/submit-manuscript.php
3. Qadir MI, Javid A (2018) Awareness about Crohn's Disease in biotechnology students. Glo Adv Res J Med Medical Sci 7(3): 62-64.

4. Qadir MI, Saleem A (2018) Awareness about ischemic heart disease in university biotechnology students. Glo Adv Res J Med Medical Sci 7(3): 59-61.

5. Qadir MI, Ishfaq S (2018) Awareness about hypertension in biology students. Int J Mod Pharma Res 7(2): 08-10.

6. Qadir MI, Mehwish (2018) Awareness about psoriasis disease. Int J Mod Pharma Res 7(2): 17-18.

7. Qadir MI, Shahzad R (2018) Awareness about obesity in postgraduate students of biotechnology. Int J Mod Pharma Res 7(2): 14-16.

8. Qadir MI, Rizvi M (2018) Awareness about thalassemia in post graduate students. MOJ Lymphology \& Phlebology 2(1): 14-16.

9. Qadir MI, Ghalia BA (2018) Awareness survey about colorectal cancer in students of M. Phil Biotechnology at Bahauddin Zakariya University, Multan, Pakistan. Nov Appro in Can Study 1(3).

10. Qadir MI, Saba G (2018) Awareness about intestinal cancer in university student. Nov Appro in Can Study 1(3).

$\begin{array}{ll}\text { BIOMEDICAL } & \text { Assets of Publishing with us } \\ \text { RESEARCHES } & \text { - Global archiving of articles } \\ & \text { - Immediate, unrestricted online access } \\ & \text { - Rigorous Peer Review Process } \\ \end{array}$

